\title{
Cadmium Toxicity Induced Changes on Morphological, Photosynthetic, Biochemical and Antioxidative Enzymes Level in Vigna mungo (L.) Hepper
}

\author{
M. Mahalakshmi, K. Marisamy, V. Ramasubramanian* \\ Department of Botany, Ayya Nadar Janaki Ammal College (Autonomous), India
}

Copyright $(2017$ by authors, all rights reserved. Authors agree that this article remains permanently open access under the terms of the Creative Commons Attribution License 4.0 International License

\begin{abstract}
Heavy metals of soils due to intensive industrial activities and agricultural development is usually a source of environmental problems. Heavy metal phytotoxicity is considered to be main factor limiting plant growth when cultivate in metal polluted soils. Heavy metals have strong impact on human health through the food chain. The aim of this study was to investigate the ill effects of cadmium on the morphological, biochemical and enzymatic characters of Vigna mungo (L.) Hepper which are commonly used in the fireworks industries of this area. After ten days treatment with different concentrations of cadmium $(2,4,6$, $8 \& 10 \mathrm{mM})$, the plant exhibited a decline in growth, chlorophyll contents, soluble sugar and protein than in the control. In contrary, the content of free amino acid, proline, leaf nitrate and the activities of enzymes such as catalase and peroxidase were found increased with the increase in the concentration of cadmium while the activity of nitrate reductase were found to be decreased. Comparison of the parameters analyzed between the treated and control reveals that cadmium have seriously affected the Vigna mungo (L.) Hepper. Based on this, it was concluded that high concentration of cadmium severely affect the plant growth and result in growth inhibition, decline in physiological and biochemical activities of crop plants.
\end{abstract}

Keywords Cadmium, Catalase, Peroxidise, Free Amino Acid, Proline and Leaf Nitrate

\section{Introduction}

Increasing environmental pollution caused by heavy metals, released by industrial and agricultural activities, is a major problem in the world [1]. Plants grown on soil with material rich in heavy metals or polluted by industrial effluents are known to absorb heavy metals in quantities that may be toxic to plant growth and metabolism [2]. Heavy metals are at the interface between the atmosphere and the earth's crust, as well as being the substrate for natural and agricultural ecosystems. Cadmium $(\mathrm{Cd})$ is a common metal pollutant introduced into the environment through industrial activities, sewage sludge application and commercial phosphorus fertilizers and subsequently become a part of the food chain [3]. It is easily taken up by plants and causes toxicity even at low concentrations [4]. It is a carcinogenic element and more available to the plants compared to other heavy metals and may thus very easily enter the human diet through food chain. Cadmium can alter the uptake of minerals from soil. The level of $\mathrm{Cd}$ in soil increases with increase in time. Plants can easily uptake cadmium and transfer it to other organs.

Currently, our study is very crucial because the soil in our area remains highly contaminated due to cadmium largely used in fireworks industries which effect most commonly cultivated Vigna mungo (L.) Hepper.thechief crop of locals. Thus there is an urgent necessity to understand the ill effects of cadmium on the crop plants mentioned and the necessary steps to be taken to overcome the problem.

\section{Material and Methods}

The seeds were soaked for $2 \mathrm{hrs}$ in water and sown in various pots containing uniformly mixed garden soil and grown separately. The metal treatments in various concentrations were given after 10 days of the plant growth. Ten days after that, the morphometric, pigmental, biochemical and enzymatic characters were analyzed.

The morphometric characters such as shoot length and root length are measured by scale and expressed in the leaf area was measured by conventional graphical method by drawing the outline of the leaf in a graph sheet and counting the small and big squares with in it and represented in $\mathrm{cm}$. The fresh weight and dry weight of the seedlings was obtained using an electronic balance. 
The pigmental characters such as chlorophyll a, chlorophyll b, total chlorophyll and carotenoids are measured by conventional method [5].

The biochemical characters such as total soluble sugars are measured by centrifugation after treating the tissue use trichloroacetic acid and anthrone as the indicator the total soluble sugars. The amino acid content was measured by homogenization of leaf tissue in ethanol and ninhydrine is the indicator of amino acid [6]. The protein content was measured by centrifugation leaf tissue in trichloroacetic acid, folin phenol with alkaline copper mixture [7]. The proline was estimated by centrifugation of leaf tissue in sulphosalicylic acid, glacial acetic acid and the proline was separated in the toluene [8]

The In vivo Nitrate Reductase (NR) activity was assayed according to [9] method with modification. Fresh leaf material (100mg) was incubated in scintillation vials containing $5 \mathrm{~mL}$ of incubation medium composed of, $100 \mathrm{mM}$ KH2PO4-KOH buffer pH 7.5, 200mM KNO3, $1 \%(\mathrm{v} / \mathrm{v}) \mathrm{n}$-Propanol and $0.1 \%(\mathrm{v} / \mathrm{v})$ Triton X 100 . Incubation was carried out in dark for one hour at room temperature with occasional shaking. Aliquots of $0.5 \mathrm{~mL}$ was taken from the vials and analysed for nitrite after 1 hour incubation. To 0.5 $\mathrm{mL}$ distilled water, $1 \mathrm{~mL}$ of $3 \%$ sulphanilamide and $1 \mathrm{~mL}$ of N-1-N (Naphthylethylenediamine dihydrochloride) were added in quick succession. Fifteen minutes were allowed for colour formation and absorbance was measured at $540 \mathrm{~nm}$.

The nitrite was estimated with the help of a standard nitrite curve. The preparation of peroxidase and catalase enzyme extracts is, the leaves of experimental plants weighing about $1 \mathrm{~g}$ was ground in $5 \mathrm{~mL}$ of $100 \mathrm{Mm}$ phosphate buffer ( $\mathrm{pH}$ 6.0) and filtered through a three layered cheese cloth and spun at $3000 \mathrm{rpm}$ for 30 minutes. The supernatant obtained was served as the source for crude enzymes such as peroxidise and catalase. To assay peroxidise activity, the enzyme extract was added to pyrogallol which gets oxidized to a coloured derivative in the presence of hydrogen peroxide $(1 \%(\mathrm{v} / \mathrm{v})$. The amount of purpurogallin formed during the reaction was assayed spectroscopically [10]. To $2 \mathrm{~mL}$ of pyrogallol phosphate buffer $(0.058 \mathrm{M}$ pyrogallol dissolved in $0.1 \mathrm{M}$ phosphate buffer $\mathrm{pH} 6.0$ ), an aliquot of $0.1 \mathrm{~mL}$ of enzyme extract was added. Then, absorbance was set to zero at $420 \mathrm{~nm}$. To this, $0.5 \mathrm{~mL}$ of $\mathrm{H}_{2} \mathrm{O}_{2}(1 \%(\mathrm{v} / \mathrm{v}))$ was added then, the content was thoroughly mixed and the absorbance was measured using systronics model no. 106 spectrophotometer. 2 The difference in the absorbance at an interval of 20 seconds for a period of 3 minutes was measured. The peroxidise activity was expressed as moles of $\mathrm{H}_{2} \mathrm{O}_{2}$ reduced per unit enzyme per unit time.

To assay the catalase activity, $3 \mathrm{~mL}$ of phosphate buffer was added to $1 \mathrm{~mL}$ of $\mathrm{H}_{2} \mathrm{O}_{2}$ and $1 \mathrm{ml}$ of enzyme extract [11]. The reaction mixture was incubated at $25^{\circ} \mathrm{C}$ for 1 minute. The reaction was terminated by the addition of $1 \mathrm{~mL}$ of $\mathrm{H}_{2}$ $\mathrm{SO}_{4}$. The reaction mixture was titrated against $0.01 \mathrm{~N}$ $\mathrm{KMNO}_{4}$. The end point was the persistence of pink colour at least for 15 seconds. The catalase activity was expressed in micromoles $\mathrm{H}_{2} \mathrm{O}_{2}$ catalysed per unit time per $\mathrm{mg}$ protein.

The heavy metal accumulation of the experimental plants was analyzed at the end of the plant life. Cobalt concentrations in plants were analyzed using the method [12].

The plant sample as a whole was washed, dried in oven at $160^{\circ} \mathrm{C}$ for 40 minutes and digested in a mixture of nitric acid and perchloric acid (10:1). Then the solution was centrifuged at $5000 \mathrm{rpm}$ for 5 minutes and double filtered with Whatman filter paper no. 4 and the filtrate was analyzed for cobalt concentration by Atomic Absorption Spectrometry (Shimadzu Model AA - 6300), available in the Science Instrumentation Centre of Ayya Nadar Janaki Ammal College (Autonomous), Sivakasi, Tamilnadu.

Statistical Analysis: For the morphometric characters the average value of ten independent samples and for the biochemical readings and enzymatic characters the average value of five were considered. The data were reported as mean $\pm \mathrm{SE}$ and the percent activity was represented in the parentheses. Statistical analysis (One way ANOVA - Turkey test) was done using the statistical package, Origin - version 7.0 .

\section{Results}

The results obtained that morphometric characters such as root length, shoot length, fresh weight, dry weight and leaf area were decreased with increasing the concentration of cadmium. The photosynthetic pigments of chlorophyll and carotenoids were decreased but the level of anthocyanin content was increased. The total soluble sugar content was decreased with the increase in the concentration of cadmium. The cadmium has caused a considerable increase in the free amino acid content than the control. The Leaf nitrate, proline, catalase activity and peroxidase activity content was increased with the increasing concentration of cadmium chloride. AAS study clearly reveals that more accumulation of Cd in Vigna mungo. 
Table 1. Effect of various concentrations of cadmium chloride on the morphometric characteristics of Vigna mungo (L.) Hepper.

\begin{tabular}{|c|c|c|c|c|c|}
\hline $\begin{array}{c}\text { Growth Parameters } \\
(\mathrm{mM})\end{array}$ & Shoot length $(\mathrm{cm})$ & Root length $(\mathrm{cm})$ & Leaf area $\left(\mathrm{cm}^{2}\right)$ & Fresh weight $(\mathrm{cm})$ & Dry weight $(\mathrm{g})$ \\
\hline Control & $23.6 \pm 0.458(100)$ & $13.2 \pm 0.28(100) *$ & $4.86 \pm 0.433(100) *$ & $0.94 \pm 0.030(100) *$ & $0.15 \pm 0.012(100) *$ \\
\hline 2 & $21.6 \pm 0.378(92) *$ & $11.8 \pm 0.493(89) *$ & $4.26 \pm 0.375(88) *$ & $0.813 \pm 0.020(87) *$ & $0.117 \pm 0.023(80) *$ \\
\hline 4 & $21.13 \pm 0.133(90) *$ & $9.73 \pm 0.371(74) *$ & $3.46 \pm 0.202(71) *$ & $0.780 \pm 0.026(83) *$ & $0.096 \pm 0.023(66) *$ \\
\hline 6 & $19.76 \pm 0.145(84) *$ & $9.26 \pm 0.145(70) *$ & $2.66 \pm 0.120(55) *$ & $0.537 \pm 0.017(57) *$ & $0.093 \pm 0.018(64) *$ \\
\hline 8 & $18.73 \pm 0.145(79) *$ & $8.1 \pm 0.208(61) *$ & $2.33 \pm 0.145(48) *$ & $0.517 \pm 0.020(55) *$ & $0.083 \pm 0.019(57) *$ \\
\hline 10 & $17.56 \pm 0.284(74) *$ & $5.0 \pm 0.264(38) *$ & $1.60 \pm 0.115(33) *$ & $0.457 \pm 0.026(49) *$ & $0.070 \pm 0.001(48) *$ \\
\hline
\end{tabular}

Values in parameters indicate percent activity; values are represents means of five observation. Values in parentheses are activity with respect to control. Mean $( \pm)$ SE. a - refers to values compared with control in various concentrations of metals, $\mathrm{a}^{*}$ - refers to significant $(\mathrm{P} \leq 0.05$ - Turkey test). a\# - refers to non - significant.

Table 2. Effect of various concentrations of cadmium chloride on the pigment content of Vigna mungo (L.) Hepper.

\begin{tabular}{|c|c|c|c|c|c|}
\hline $\begin{array}{c}\text { Cadmium chloride } \\
(\mathrm{mM})\end{array}$ & $\begin{array}{c}\text { Chlorophyll a } \\
(\mathrm{mg} / \mathrm{g} \text { LFW })\end{array}$ & $\begin{array}{c}\text { Chlorophyll b } \\
(\mathrm{mg} / \mathrm{g} \text { LFW })\end{array}$ & $\begin{array}{c}\text { Total chlorophyll } \\
(\mathrm{mg} / \mathrm{g} \text { LFW })\end{array}$ & $\begin{array}{c}\text { Carotenoids } \\
(\mathrm{mg} / \mathrm{g} \text { LFW })\end{array}$ & $\begin{array}{c}\text { Anthocyanin } \\
(\mathrm{mg} / \mathrm{g} \text { LFW })\end{array}$ \\
\hline Control & $3.73 \pm 0.681(100)$ & $4.43 \pm 0.155(100)$ & $7.20 \pm 0.618(100)$ & $6.32 \pm 0.054(100)$ & $0.39 \pm 0.107(100)$ \\
\hline 2 & $2.02 \pm 0.228(73)^{*}$ & $2.72 \pm 0.132(58)^{*}$ & $4.72 \pm 0.346(66)^{*}$ & $4.15 \pm 0.030(65)^{*}$ & $0.43 \pm 0.251(109)^{*}$ \\
\hline 4 & $1.13 \pm 0.152(57)^{*}$ & $2.39 \pm 0.364(41)^{*}$ & $3.53 \pm 0.513(49)^{*}$ & $3.10 \pm 0.045(48)^{*}$ & $0.55 \pm 0.051(138)^{*}$ \\
\hline 6 & $1.09 \pm 0.112(53)^{*}$ & $1.97 \pm 0.176(29)^{*}$ & $2.99 \pm 0.279(41)^{*}$ & $2.64 \pm 0.024(42)^{*}$ & $0.62 \pm 0.102(157)^{*}$ \\
\hline 8 & $1.52 \pm 0.079(41)^{*}$ & $1.99 \pm 0.101(28)^{*}$ & $2.51 \pm 0.178(33)^{*}$ & $2.21 \pm 0.015(35)^{*}$ & $0.70 \pm 0.279(175)^{*}$ \\
\hline 10 & $1.32 \pm 0.080(35)^{*}$ & $1.93 \pm 0.087(27)^{*}$ & $2.25 \pm 0.167(30)^{*}$ & $1.98 \pm 0.014(32)^{*}$ & $0.78 \pm 0.037(197)^{*}$ \\
\hline
\end{tabular}

Values in parameters indicate percent activity; values are represents means of five observation. Values in parentheses are activity with respect to control. Mean $( \pm)$ SE. a - refers to values compared with control in various concentrations of metals, $\mathrm{a}^{*}$ - refers to significant $(\mathrm{P} \leq 0.05$ - Turkey test $)$. a\# - refers to non - significant.

Table 3. Effect of various concentrations of cadmium chloride on the biochemical characteristics of Vigna mungo (L.) Hepper.

\begin{tabular}{|c|c|c|c|c|c|}
\hline $\begin{array}{c}\text { Cadmium chloride } \\
(\mathrm{mM})\end{array}$ & $\begin{array}{c}\text { Total soluble sugar } \\
(\mathrm{mg} / \mathrm{g} \text { LFW })\end{array}$ & $\begin{array}{c}\text { Total soluble protein } \\
(\mathrm{mg} / \mathrm{g} \text { LFW })\end{array}$ & $\begin{array}{c}\text { Amino acid } \\
(\mu \mathrm{Mole} / \mathrm{g} \text { LFW })\end{array}$ & Proline $(\mathrm{mg} / \mathrm{g}$ LFW $)$ & $\begin{array}{c}\text { Leaf nitrate } \\
(\mathrm{mg} / \mathrm{g} \text { LFW })\end{array}$ \\
\hline Control & $3.33 \pm 0.105(100)$ & $8.338 \pm 0.033(100)$ & $4.196 \pm 0.075(100)$ & $3.167 \pm 0.012(100)$ & $6.633 \pm 0.001(100)$ \\
\hline 2 & $3.006 \pm 0.124(90)^{*}$ & $6.847 \pm 0.041(83)^{*}$ & $4.755 \pm 0.151(113)^{*}$ & $3.960 \pm 0.014(125)^{*}$ & $7.493 \pm 0.004(113)^{*}$ \\
\hline 4 & $2.833 \pm 0.145(85)^{*}$ & $5.932 \pm 0.039(72)^{*}$ & $5.100 \pm 0.115(122)^{*}$ & $4.927 \pm 0.026(156)^{*}$ & $8.926 \pm 0.002(135)^{*}$ \\
\hline 6 & $2.580 \pm 0.221(77)^{*}$ & $4.881 \pm 0.037(59)^{*}$ & $6.562 \pm 0.152(156)^{*}$ & $5.833 \pm 0.015(184)^{*}$ & $10.14 \pm 0.001(153)^{*}$ \\
\hline 8 & $2.313 \pm 0.145(69)^{*}$ & $3.932 \pm 0.033(47)^{*}$ & $7.848 \pm 0.482(187)^{*}$ & $6.347 \pm 0.010(201)^{*}$ & $11.97 \pm 0.002(181)^{*}$ \\
\hline 10 & $1.513 \pm 0.219(45)^{*}$ & $2.983 \pm 0.041(36)^{*}$ & $8.160 \pm 0.116(195)^{*}$ & $6.944 \pm 0.013(220)^{*}$ & $12.70 \pm 0.002(192)^{*}$ \\
\hline
\end{tabular}

Values in parameters indicate percent activity; values are represents means of five observation. Values in parentheses are activity with respect to control. Mean $( \pm)$ SE. a - refers to values compared with control in various concentrations of metals, $\mathrm{a}^{*}$ - refers to significant $(\mathrm{P} \leq 0.05$ - Turkey test). a\# - refers to non - significant.

Table 4. Effect of various concentrations of cadmium chloride on the enzymatic characteristics of Vigna mungo (L.) Hepper.

\begin{tabular}{|c|c|c|c|}
\hline Cadmium chloride $(\mathrm{mM})$ & NR Activity $(\mu$ Mole $/ \mathrm{g}$ LFW) & Catalase $(\mu$ Mole $/ \mathrm{g}$ LFW $)$ & Peroxidase $(\mu$ Mole/g LFW) \\
\hline Control & $5.108 \pm 0.075(100)$ & $0.707 \pm 0.038(100)$ & $5.012 \pm 0.011(100)$ \\
\hline 2 & $4.333 \pm 0.040(85)^{*}$ & $1.066 \pm 0.039(146)^{*}$ & $6.793 \pm 0.071(136)^{*}$ \\
\hline 4 & $3.541 \pm 0.066(69)^{*}$ & $1.373 \pm 0.058(188)^{*}$ & $7.384 \pm 0.047(147)^{*}$ \\
\hline 6 & $2.283 \pm 0.097(52)^{*}$ & $1.488 \pm 0.080(203)^{*}$ & $8.661 \pm 0.071(173)^{*}$ \\
\hline 8 & $2.65 \pm 0.040(45)^{*}$ & $1.600 \pm 0.101(218)^{*}$ & $9.061 \pm 0.046(181)^{*}$ \\
\hline 10 & $1.75 \pm 0.016(34)^{*}$ & $1.711 \pm 0.211(233)^{*}$ & $10.59 \pm 0.044(211)^{*}$ \\
\hline
\end{tabular}

Values in parameters indicate percent activity; values are represents means of five observation. Values in parentheses are activity with respect to control. Mean $( \pm)$ SE. a - refers to values compared with control in various concentrations of metals, $\mathrm{a}^{*}$ - refers to significant $(\mathrm{P} \leq 0.05$ - Turkey test $)$. a\# - refers to non - significant. 
Table 5. AAS Study on the Concentration of Cadmium in Vigna mungo (L.) Hepper (Blackgram)

\begin{tabular}{|c|c|}
\hline Parameters & AAA in ppm \\
\hline Control & Nil \\
\hline $2 \mathrm{mM}$ & $0.1609 \mathrm{ppm}$ \\
\hline $4 \mathrm{mM}$ & $0.2123 \mathrm{ppm}$ \\
\hline $6 \mathrm{mM}$ & $0.2623 \mathrm{ppm}$ \\
\hline $8 \mathrm{mM}$ & $0.2804 \mathrm{ppm}$ \\
\hline $10 \mathrm{mM}$ & $0.4258 \mathrm{ppm}$ \\
\hline
\end{tabular}

\section{Discussion}

Heavy metal pollution has developed as an ecological problem, which threatens primary and secondary consumers and finally human beings. Cadmium is an important pollutant with high toxicity towards plants and is expected to negatively affect plant growth [13]. Morphology is one of the important parameter to monitor the effect of toxic metals on plants. Plants show marked differences in extent of root length, shoot length, fresh weight and dry weight were analysed. Shoot and root length were decreased with increasing concentrations of cadmium. Similar results were observed by Marisamy et al., [14] in Helianthus annuus (L.) under barium treatment. According to Symeonidis and Karataglis, [15] the reduction of morphological growth parameters is directly related to reduction of the chlorophyll content in the leaves as a result of heavy metal stress is well known and is probably caused either by the direct influence of these metals on chlorophyll synthesis or by the obstruction of chlorophyll synthesizing pathway. The protective function of the plant anthocyanin against the stress condition is fairly clear $[16,17]$ increase in the anthocyanin content after cadmium treatment was observed in metal treated plants. The decrease in chlorophyll content was also reported in Eleusine coracana (L.) under copper stress [18] and in Eleusine coracana (L.) under cobalt treatment [19]. Decrease in soluble sugar content by the treatment of cadmium was reported by Marisamy et al., [20] under the strontium treatment in Amaranthus caudatus Linn. According to Singh and Tewari [21] Protein content in organisms is an important indicator of reversible and irreversible changes in metabolism, was known to respond to a wide variety of stresses such as natural and xenobiotic. Metal induced inhibition of protein synthesis was reported by Marisamy et al., [22]. Proline has been suggested to play multiple functions in plant tolerance to stress. Protective role of proline has been attributed to its ability to act as osmoprotectant [23, 24, 25].The accumulation of leaf nitrate content was found to be associated with a reduction in in vivo nitrate Reductase activity. Leaf nitrate content was increased with the increase in the concentration of cadmium chloride [26] observed a reduction in NR activity and also correlated with the leaf nitrate content. The enzymatic antioxidant system is a protective mechanism that operates with the sequential and simultaneous action of various enzymes including peroxidase (POD) and catalase (CAT) $[27,28]$.

\section{Conclusions}

In present study, Cadmium is an important pollutant with high toxicity towards plants and is expected to negatively affect plant growth. The environmental degradation, promoted mainly by anthropogenic action, has imposed strong pressure on the quality of ecosystems. Cd occurs naturally at a low concentration in the soil, but its level has been steadily increasing due to mining and smelting, dispersal of sewage sludge and the use of $\mathrm{Cd}$ rich phosphate fertilizers.

\section{Acknowledgements}

The author is very much thankful to Dr. V. Ramasubramanian, Associate Professor and Head Department of Plant Biology and Plant Biotechnology, ANJA College, Sivakasi for their guidance and the management of ANJA College, Sivakasi for providing necessary facilities to carry out the present study.

\section{REFERENCES}

[1] Prasad, M.N.V. (2004). Heavy metal stress in plants from biomolecules to ecosystems. 2nd edition, Narosa Publishing house, 22 Dyryaganj, New Delhi.

[2] Alloway, B.J., (1990). Heavy Metals in Soils. John Wiley, New York.

[3] Wagner, G. J. (1993). Accumulation of cadmium in crop plants and its consequences to human health. Adv. Agron., 51: 173-205.

[4] Sanita di Troppi, L. and Gabbrielli, R. (1999). Response to cadmium in higher plants. Environ. ofExperi. Bot., 41: 105-130.

[5] Wellburn, A.R. and H. Lichtenthaler, (1984). In Advances in photosynthesis Research, (ed. Sybesma) Martinus Nijhoff, Co. The Hague. II: 9-12.

[6] Jayaraman, J., (1981). Laboratory manual in Biochemistry, Willey-Eastern Company Limited, Madras, pp: 1-65.

[7] Lowry, O.H., N.J. Rosenbury, A.L. Farr and R.J. Randall, (1951). Protein measurement with folin phenol reagent. J. Bio. Chem., 193: 262-275.

[8] Bates, L.S., R.P. Waldren and I.D. Teare, (1973). Rapid determination of the proline in water stress studies. Plant and Soil, 39: 205-208.

[9] Jaworski, E.G. (1971). Nitrate reductase assay in intact plant tissues. Biochem. Biophy. Res. Commun., 43: 1274-1279.

[10] Addy, S.K. and R.N. Goodman, (1972). Polyphenol oxidase 
and peroxidise activity in apple leaves inoculated with a virulent or avirulent strain for Erwiniaamylovora. Indian Phytopath., 25: 575-579.

[11] Kar, M. and D. Mishra, (1976). Catalase, peroxidase and polyphenol oxidase activities during rice leaf senescence. Plant Physiol., 57: 315-319.

[12] Jayakumar, K. and Cheruth Abdul Jaleel, (2009). Uptake and Accumulation of Cobalt in Plants: a Study Based on Exogenous Cobalt in Soybean. Botany Research International, 2(4): 310-314.

[13] Benavides, M.P., Gallego, S.M. and Tomaro, M.L. (2005). Cadmium toxicity in plants. Braz. J. Plant Physiol., 17: 21-34.

[14] Marisamy, K., Duraipandian, M., Sevugaperumal, R and Ramasubramanian, V. 2016. Barium toxicity induced changes on growth, photosynthetic, biochemical and antioxidative enzymes level in Helianthus annuus(L.). International Journal of Recent Scientific Research, 7(3):9781-9787.

[15] Symeonidis, L., Karataglis, S. (1992). Interactive effects of cadmium, lead and zinc on root growth of two metal tolerant genotypes of Holcuslanatus L.Biometals., 5:173-178.

[16] Caldwell, M.M. (1981). In: Enzyclopedia of plant physiology, New series Eds. Lange. O.L., Novel, P.S., Osmond, C.B. and Ziegler, H. 12 (A): 169-198.

[17] Mishra, S. and Agrawal, S.B. (2006). Interactive effects between supplemental UV-B radiation and heavy metals on growth and biochemical characteristics of Spinaciaoleracea $L$. Braz. J. Plant Physiol., 18: 1-8.

[18] Duraipandian,M., Periyanayagi, G., Marisamy, K., Sevugaperumal, R., Ganesh, D and Ramasubramanian, V. 2015. Amelioration of Copper Caused Stress in Terms of Morphometric, Pigmental, Biochemical and Enzymatic Characteristics of Eleusinecoracana (L.) Gaertn. Global Journal of Environmental Research. 9(2): 10-13.

[19] Duraipandian, M., Marisamy, K., Periyanayagi, G., Sevugaperumal, R., Ganesh, D and Ramasubramanian, V. 2016. Impact of cobalt on the growth, pigmental, some biochemical and enzymatic characteristics of
Eleusinecoracana (L.) Gaertn. American-Eurasian Journal of Toxicological Sciences. 8(3): 115-119.

[20] Marisamy, K., Sevugaperumal R. and Ramasubramanian, V. Effect of Metal Stress due to Strontium and The Mechanisms of Tolerating it by Amaranthus caudatus Linn. Biochem Physiol 5(3): 1-6.

[21] Singh, P.K. and Tewari, S.K. (2003). Cadmium toxicity induced changes in plant water relations and oxidative metabolism of Brassica juncea L. plants. J. Environ.Biol., 24: 107-117.

[22] Marisamy, K., Sevugaperumal, R. and Ramasubramanian, V. 2016. Effect of metal stress due to strontium and the mechanisms of tolerating it by Amaranthuscaudatus Linn. Biochemistry \& Physiology. 5(3): 1-6

[23] Samantary, S. (2000). Biological response of chromium tolerant and chromium sensitive Mung bean, cultivers growth on varying level of chromium. Chemosphere., 47: 1065-1072.

[24] Hartzendorf, T. and Rolletschek, H. (2001). Effect of NaClsalinity on amino acid and carbohydrate con tents of Phragmitesaustralis. Aquat. Bot., 69: 195-208.

[25] Marisamy, K., Sevugaperumal, R. and Ramasubramanian, V. 2015. Changes in growth, biochemical and enzymatic characteristics of Cyamopsis tetragonoloba (L.) Taub under metal stress due to barium. International Journal of Biological \& Pharmaceutical Research. 6(12): 935-938.

[26] Huffaker, R.C., Klobus, G. and Ward, G.R. (1988). Characteristics of injury and recovery of net No- 3 transport of barley seedlings from treatments of $\mathrm{NaCl}$. Plant Physiol., 87:878-882.

[27] Shah, K., Kumar, R.G., Verma, S., Dubey, R.S. (2001). Effect of cadmium on lipid peroxidation, superoxide anion generation and activities of antioxidant enzymes in growing rice seedlings. Plant Sci., 161:1135-1144.

[28] Arundhathi, A., Marisamy, K., Duraipandian, M., Sevugaperumal, R. and Ramasubramanian, V. 2016. Comparison of the Metal Toxicity due to Aluminium and Barium on the Growth Attributes of Vigna trilobata $(\mathrm{L}$.) Verde. Bioengineering and Bioscience 4(4): 64-69. 